Jurnal Civics: Media Kajian Kewarganegaraan
https://journal.uny.ac.id/index.php/civics/index
$1829-5789$ (print)
$2541-1918$ (online)

\title{
Hubungan kompetensi pedagogis dan kompetensi profesional guru PPKn dengan prestasi belajar siswa sekolah menengah
}

\author{
Vinta Larasati ${ }^{\text {a, }}{ }^{*}$, Abdul Gafur ${ }^{\text {b, } 2}$ \\ a, b Program Pascasarjana, Universitas Negeri Yogyakarta, Sleman, Indonesia \\ ${ }^{1}$ vilsasaja@yahoo.com*; abdul_gafur@uny.ac.id \\ *korespondensi penulis
}

\begin{tabular}{ll}
\hline \multicolumn{2}{l}{ Informasi artikel } \\
\hline Sejarah artikel: & \\
Diterima & $: 09-12-2017$ \\
Revisi & $: 10-03-2018$ \\
Dipublikasikan & $: 31-05-2018$ \\
\hline
\end{tabular}

Kata kunci:

Kompetensi guru

Prestasi belajar

PPKn

\begin{abstract}
ABSTRAK
Tujuan penelitian ini adalah untuk mengetahui hubungan kompetensi pedagogis dan kompetensi profesional guru PPKn dengan prestasi belajar siswa di SMA Negeri se-Kota Yogyakarta. Metode penelitian ini adalah korelasional dengan pendekatan kuantitatif. Data penelitian dikumpulkan melalui angket dan dokumentasi. Analisis data untuk pengujian hipotesis menggunakan korelasi product moment sederhana dan regresi berganda. Hasil penelitian membuktikan bahwa: 1) Terdapat hubungan positif dan signifikan antara kompetensi pedagogis guru PPKn dengan prestasi belajar PPKn siswa. Kekuatan hubungan menunjukkan arah kekuatan dalam kategori sangat kuat. 2) Terdapat hubungan positif dan signifikan antara kompetensi profesional guru PPKn dengan prestasi belajar PPKn siswa. Kekuatan hubungan antara kedua variabel menunjukkan arah dalam kategori sangat kuat. 3) Terdapat hubungan positif dan signifikan kompetensi pedagogis dan kompetensi profesional guru PPKn dengan prestasi belajar siswa.
\end{abstract}

Keywords:

Teacher's competence

Learning achievement

PPKn

\begin{abstract}
The relationship of pedagogical and professional competence of civic education teachers with student achievement in senior high school in Yogyakarta. This research was aimed at explaining the relationship between pedagogical and professional competency among PPKn teachers and students' achievement at SMAN (State-owned Senior High Schools) in Yogyakarta city. It was a correlational study with quantitative approach. Data was analyzed statistically to test the hypotheses using product moment test. The results are follows. 1) there is a positive and significant correlation between teachers' pedagogical competency and students' achievement. 2) there is a positive and significant correlation between teachers ' professional competency and students' achievement. 3) there is a positive and significant correlation between teachers' pedagogical and professional competency and students' achievement.
\end{abstract}

Copyright $\odot 2018$ Vinta Larasati dan Abdul Gafur

\section{Pendahuluan}

Guru merupakan salah satu faktor yang mempengaruhi prestasi belajar siswa, karena untuk menghasilkan prestasi belajar siswa yang baik, hendaknya siswa dididik oleh guru yang memiliki kompetensi di bidang 
pendidikan itu sendiri. Kompetensi yang dimiliki oleh guru akan mempengaruhi pola kepemimpinan guru ketika mengajar di kelas. Cara guru menyampaikan materi pelajaran akan berpengaruh terhadap pemahaman siswa dan berimbas pada prestasi belajarnya. Metode pembelajaran yang digunakan oleh guru memiliki pengaruh yang lebih besar terhadap prestasi belajar siswa (Lee \& Rha, 2009, hal. 380). Penelitian yang telah dilakukan Tatar, Tüysüz, Tosun, \& Ilhan (2016, hal. 156) juga menegaskan bahwa guru memberikan pengaruh yang besar terhadap prestasi belajar siswa, yaitu sebanyak $29,66 \%$ prestasi siswa dipengaruhi oleh guru, $26,05 \%$ oleh siswa, $16,02 \%$ oleh materi, $14,98 \%$ oleh kurikulum dan 13,29\% oleh lingkungan belajar. Sebagai seorang pendidik maka guru harus memiliki beberapa kompetensi untuk menunjang kinerjanya.

Berdasarkan Peraturan Pemerintah Nomor 32 Tahun 2013 Tentang Standar Nasional Pendidikan, dinyatakan bahwa "kompetensi yang harus dimiliki oleh guru meliputi kompetensi pedagogis, kompetensi kepribadian, kompetensi sosial, kompetensi profesional yang diperoleh melalui pendidikan profesi". Keempat kompetensi ini dibutuhkan dalam aktivitas pendidikan dan sebagai pedoman perilaku bagi guru dalam melaksanakan tugas sebagai pendidik.

Guru bisa membimbing dan mengarahkan potensi yang dimiliki oleh peserta didik jika guru memiliki semua kompetensi tersebut, sehingga akan memungkinkan tercapainya prestasi belajar yang bagus. Kompetensi guru merupakan modal utama bagi guru untuk melaksanakan profesinya, karena kompetensi yang tinggi akan menghasilkan output yang baik (Widarsih \& Faraz, 2016, hal. 179). Output di sini bisa diartikan sebagai hasil belajar dan prestasi peserta didik. Namun, kompetensi pedagogis dan kompetensi profesional yang sangat dekat perannya dalam menunjang kinerja guru dalam proses pembelajaran.

Loughran, Berry, \& Mulhall (2012, hal. 4) berpendapat, pedagogis adalah istilah yang digunakan dalam pendidikan yang dirancang untuk membuat pembicaraan tentang pengajaran tampak lebih canggih dan tidak seperti praktik pendidikan yang kebanyakan masih bermasalah. Pedagogis sering digunakan sebagai sinonim untuk pengajaran. Pada tradisi Eropa, pedagogis lebih berkaitan dengan pemahaman hubungan antara pengajaran dan pembelajaran dengan cara menumbuhkan perkembangan-perkembangan dan pertumbuhan anak. Guru yang menguasai kompetensi pedagogis dapat membuat kesesuaian terhadap praktik pendidikan. Guru bisa membedakan apa yang tepat dan kurang tepat untuk peserta didik. Guru yang memiliki kompetensi pedagogis bukan hanya guru yang mengantongi pengetahuan tentang trik-trik mengajar yang baik saja, tetapi mampu merealisasikan dan menyesuaikan dengan keadaan kelas. Kompetensi pedagogis sangat menunjang kinerja guru saat melaksanakan proses pembelajaran, karena guru dapat melakukan pengelolaan proses pembelajaran di kelas menjadi lebih efektif. Guru memahami bagaimana karakter siswanya, guru mahir dalam membuat rancangan pembelajaran yang sinkron dengan pelaksanaan pembelajaran, guru bisa mengevaluasi hasil belajar dengan tepat sehingga dapat mengembangkan kemampuan siswa.

Selain dari kompetensi pedagogis yang dapat menunjang kinerja guru, kompetensi profesional juga harus dimiliki guru, supaya dapat membimbing siswa dalam proses pembelajaran. Kompetensi profesional merupakan kemampuan guru dalam penguasaan materi pembelajaran secara luas dan mendalam yang memungkinkan membimbing peserta didik memenuhi standar kompetensi yang ditetapkan dalam Standar Nasional Pendidikan.

Implikasi penelitian yang dilakukan oleh Akiba \& Liang (2016, hal. 8) bahwasanya sekolah penting membangun profesional guru jika ingin meningkatkan prestasi belajar siswa, hal ini dikarenakan guru yang profesional dapat berkomunikasi dengan baik dengan peserta didik, sehingga akan terciptanya proses pembelajaran kolaborasi yang baik antara guru dan peserta didik. 
Dapat disimpulkan dari pengertian di atas, maka pengertian guru profesional adalah orang yang memiliki kemampuan dan keahlian khusus dalam bidang keguruan sehingga ia mampu melakukan tugas dan fungsinya sebagai guru dengan kemampuan yang maksimal. Proses belajar dan hasil belajar para siswa bukan saja ditentukan oleh sekolah, pola, struktur, dan isi kurikulumnya, akan tetapi sebagian besar ditentukan oleh kompetensi guru yang mengajar dan membimbing mereka (Hamalik, 2009, hal. 36).

Salah satu cara yang dapat meningkatkan prestasi belajar siswa adalah dengan meningkatkan kualitas pendidikan dan meningkatkan kualitas mengajar guru, karena guru merupakan orang yang secara langsung berinteraksi dengan siswa di kelas, mengenal bagaimana karakteristik siswa, melakukan pengelolaan kelas dan membimbing kompetensi yang dimiliki masing-masing siswa.

Berdasarkan pra penelitian yang dilakukan pada bulan Maret 2016 di sekolah SMA Negeri se-Kota Yogyakarta, terdapat proses pembelajaran yang terkadang berpusat pada guru dan di sekolah lainnya terkadang berpusat kepada siswa. Guru belum membiasakan melakukan inovasi pada metode mengajarnya, sehingga proses pembelajaran berjalan satu arah. Berdasarkan data yang diperoleh dari masing-masing sekolah SMA Negeri se-Kota Yogyakarta, masih banyak terdapat siswa yang memiliki nilai PPKn di bawah KKM dan belum seratus persen tuntas di setiap kelas.

Pendidikan Kewarganegaraan merupakan salah satu mata pelajaran yang memberikan pengajaran tentang bagaimana menjadi warganegara yang baik, mengajarkan moral, namun para siswa cenderung menilai bahwa pelajaran ini membosankan, karena pelajaran ini terkesan hafalan dan teritik apalagi jika hanya guru yang mendominasi proses pembelajaran. Berdasarkan keadaan yang telah digambarkan, peneliti melakukan sebuah penelitian untuk meneliti apakah faktor guru PPKn terutama kompetensi pedagogis dan kompetensi profesional guru memiliki hubungan yang kuat dalam mempengaruhi prestasi belajar PPKn siswa.

Tujuan penelitian ini untuk memperoleh gambaran hubungan kompetensi pedagogis dan kompetensi profesional guru PPKn dengan prestasi belajar siswa di SMA Negeri se-Kota Yogyakarta. Penelitian ini diharapkan akan bermanfaat dan memberikan kontribusi bagi pihak sekolah, dapat memberikan masukan serta gambaran mengenai kompetensi pedagogis dan profesional guru yang berkontribusi dalam meningkatkan prestasi belajar siswaJurnal Civics

\section{Metode}

Penelitian ini merupakan penelitian korelasi karena penelitian ini bertujuan untuk menetapkan arah dan besarnya hubungan antar variabel-variabel yang diteliti. Pendekatan yang digunakan adalah pendekatan kuantitatif, karena informasi data yang diperoleh disajikan dalam bentuk angkaangka dan dianalisis menggunakan analisis statistik. Hal ini sebagaimana yang dikemukakan Sugiyono (2012) bahwa pendekatan kuantitatif menggunakan statistik untuk menguji hipotesis. Penelitian ini dilaksanakan di SMA Negeri se-Kota Yogyakarta, pada bulan Januari sampai bulan Maret 2017. Populasi dalam penelitian ini adalah seluruh guru PPKn di SMA Negeri seKota Yogyakarta yang berjumlah 22 orang. Pengumpulan data yang digunakan kuesioner dan dokumentasi. Kuesioner digunakan untuk memperoleh data tentang kompetensi pedagogis dan kompetensi profesional yang di isi oleh guru PPKn. Dokumentasi dokumen yang digunakan dalam penelitian ini adalah nilai rata-rata Raport PPKn siswa dari masing-masing sekolah. Dokumen tersebut untuk memperoleh data prestasi belajar siswa. Data yang dikumpulkan saat penelitian selanjutnya dianalisis, adapun untuk menganalisis data yang telah dikumpulkan, perlu dilakukan uji prasyarat terlebih dahulu. Uji prasyarat analisis dimaksudkan untuk mengetahui apakah data yang dikumpulkan memenuhi syarat untuk dianalisis dengan teknik statistik yang dipilih. Uji prasyarat itu sendiri meliputi uji normalitas, uji linieritas 
dan uji multikolinearitas. Pengujian hipotesis dalam penelitian. Hipotesis pertama, dan kedua diuji dengan korelasi product moment (hubungan satu variabel independen dengan satu variabel dependen). Hipotesis ketiga diuji dengan menggunakan regresi berganda (hubungan antara dua atau lebih variabel independen terhadap satu atau lebih variabel dependen).

\section{Hasil dan Pembahasan}

Analisis yang dilakukan untuk pengujian hipotesis dalam penelitian ini adalah analisis korelasi dengan menggunakan Product Moment, caranya dengan membandingkan $r$ hitung dengan $r$ tabel. Hipotesis diterima jika $r$ hitung lebih besar daripada $r$ tabel $(r$ hitung $>r$ tabel $)$ dan memiliki nilai signifikansi kurang dari 0,05 (signifikansi < 0,05) yang terlebih dahulu telah dilakukan uji persyaratan.

Hipotesis pertama yang terdapat dalam penelitian ini adalah terdapat hubungan yang positif dan signifikan pada kompetensi pedagogis guru Pendidikan Kewarganegaraan dengan prestasi belajar PPKn siswa di SMA Negeri Se-Kota Yogyakarta". Hipotesis tersebut kemudian diuji menggunakan SPSS 21 for Windows, dan hasilnya bahwa nilai $r$ hitung lebih besar daripada $r_{\text {tabel }}(0,822>0,602)$ dan memiliki nilai signifikansi kurang dari 0,05 yaitu $0,002(0,002<0,05)$, sehingga dapat disimpulkan bahwa hipotesis pertama diterima yaitu terdapat hubungan yang positif dan signifikan pada kompetensi pedagogis guru dengan prestasi belajar PPKn siswa SMA Negeri se-Yogyakarta. Nilai korelasi Pearson Product Moment yang diperoleh dari analisis yang telah dilakukan menunjukkan nilai 0,822 jika diinterpretasikan kekuatan hubungan antara dua variabel yaitu kompetensi pedagogis guru dengan prestasi belajar PPKn siswa SMA Negeri se-Kota Yogyakarta menunjukkan arah kekuatan hubungan dalam kategori sangat kuat.

Berdasarkan hasil uji hipotesis yang telah dilakukan, maka dapat mendukung penelitian yang telah dilakukan oleh Indra (2016, hal. 106) menunjukkan hasil bahwa variabel kompetensi pedagogis guru berpengaruh positif terhadap prestasi belajar siswa. Hal ini dikarenakan dalam kompetensi pedagogis, guru dituntut untuk menguasai wawasan kependidikan, pemahaman terhadap perkembangan siswa, pengembangan kurikulum dan silabus, pembelajaran yang mendidik dan dialogis antara guru dan siswa, dan pengembangan potensi siswa, serta mampu mengevaluasi prestasi belajar siswa.

Pada proses pembelajaran dan supaya terciptanya hasil belajar yang baik, maka kompetensi guru sangatlah berperan penting, karena proses belajar mengajar dan hasil belajar para siswa bukan saja ditentukan oleh sekolah, pola, dan isi kurikulumnya, akan tetapi juga ditentukan oleh kompetensi guru yang mengajar dan membimbing para siswa. Guru yang berkompeten akan lebih mampu mengelola kelasnya, sehingga belajar para siswa berada pada tingkat optimal (Hamalik, 2009, hal. 36).

Di dalam rincian tentang kompetensi pedagogis guru pada lampiran Peraturan Menteri Pendidikan Nasional Nomor 16 tahun 2007 tentang Standar Kualifikasi Akademik dan Kompetensi Guru terdapat indikator berkomunikasi dengan peserta didik, Pada kompetensi ini guru akan dilihat cara berkomunikasi dengan peserta didik, baik itu cara berbicara atau menanggapi pendapat dari peserta didik. Pernyataan ini diungkapkan pula oleh Payong (2011) bahwa guru harus dapat berkomunikasi secara efektif dengan siswa agar pesan-pesan pembelajaran dapat dipahami, dihayati atau diamalkan oleh para siswa. Untuk mencapai komunikasi yang efektif maka diperlukan adanya pendekatanpendekatan dengan peserta didik pada saat pembelajaran salah satunya dengan menggunakan bahasa yang santun sesuai dengan yang diungkapkan oleh Payong (2011, hal. 40) bahwa dalam pergaulan dan interaksi edukatif guru dan siswa dibutuhkan komunikasi yang santun.

Memperlakukan peserta didik dengan adil turut menyumbangkan pengaruh terhadap keberhasilan yang akan dicapai oleh peserta didik. Hasil penelitian menunjukkan persepsi siswa yang diperlakukan adil dan sugestif serta gaya mengajar guru yang interaktif di kelas dapat membantu peserta didik untuk 
berprestasi (An, Hannum, \& Sargent, 2008, hal. 309-334). Penelitian yang dilakukan oleh Wulandari (2012, hal. 29) juga menunjukkan hasil bahwa kompetensi pedagogis guru berpengaruh positif dan signifikan terhadap prestasi belajar siswa, hal ini dikarenakan guru dapat mendorong minat dan semangat belajar siswa, guru harus mampu memahami karakter siswa, melakukan rancangan pembelajaran dan bahkan dituntut untuk bisa mengaktualisasikan berbagai potensi yang dimiliki siswa. Berdasarkan hasil analisis hipotesis dan kajian teori yang ditemukan dapat disimpulkan bahwa kompetensi pedagogis guru Pendidikan kewarganegaraan memiliki hubungan positif dan signifikan dengan prestasi belajar PPKn siswa.

Hipotesis kedua dalam penelitian ini adalah terdapat hubungan yang positif dan signifikan pada kompetensi profesional guru Pendidikan Kewarganegaraan dengan prestasi belajar PPKn siswa di SMA Negeri se- Kota Yogyakarta". Berdasarkan hasil uji analisis korelasi yang telah dilakukan, dapat diketahui bahwa nilai $r$ hitung lebih besar daripada $r$ tabel $(0,819>0,602)$ dan memiliki nilai signifikansi kurang dari 0,05 yaitu 0,002 $(0,002<0,05)$, sehingga dapat disimpulkan bahwa Ha2 diterima yaitu terdapat hubungan yang positif dan signifikan pada kompetensi profesional guru dengan prestasi belajar PPKn Siswa SMA Negeri se-Yogyakarta. Nilai person korelasi yang diperoleh dari analisis yang telah dilakukan menunjukkan nilai 0,819 jika diinterpretasikan kekuatan hubungan antara dua variabel yaitu kompetensi profesional guru dengan prestasi belajar PPKn siswa SMA Negeri se-Kota Yogyakarta menunjukkan arah kekuatan hubungan dalam kategori sangat kuat.

Hasil penelitian yang diperoleh dapat membuktikan pendapat dari Tatar et al. (2016, hal. 156) menegaskan bahwa guru memberikan pengaruh yang besar terhadap prestasi belajar siswa, yaitu sebanyak $29,66 \%$ prestasi siswa dipengaruhi oleh guru, 26,05\% oleh siswa, $16,02 \%$ oleh materi, $14,98 \%$ oleh kurikulum dan 13,29\% oleh lingkungan belajar. Pada proses pembelajaran guru yang profesional merupakan indikator kunci terhadap reformasi sekolah, karena guru memiliki pengetahuan praktis, dapat merupakan indikator kunci terhadap reformasi sekolah, karena guru memiliki pengetahuan praktis, memiliki pandangan internal tentang pengajaran dan pembelajaran yang baik, dapat membimbing pekerjaan mereka untuk berinteraksi dengan siswa dan rekan kerja (Kosunen \& Mikkola, 2002, hal. 135).

Sebagai guru yang memiliki kontribusi untuk menjamin kelancaran sistem pendidikan, guru harus selalu mengembangkan kemampuannya dari segi apapun terutama teknologi yang setiap saat berkembang dengan cepat. Dalam praktik pendidikan modern, seperti teknologi komputer, teknologi informasi, teknologi multimedia, dan teknologi internet telah banyak digunakan. Maka, guru harus mampu menguasai teknologi yang terus berkembang dan hal itu sudah harus menjadi keterampilan dasar guru, karena hal tersebut merupakan salah satu upaya yang bisa dilakukan untuk melakukan pengembangan profesionalisme guru (Jiang, 2017, hal. 2). Seseorang yang profesional seperti guru maka guru tersebut dapat mengukur kapasitas dan prestasi siswanya dan dapat mengarahkan siswanya ke jalur yang tepat (Connell, 2009, hal. 216).

Terdapat sumbangan efektif dan relatif menunjukkan bahwa kompetensi profesional guru memiliki pengaruh terhadap prestasi belajar PPKn siswa sebesar 39,94\%. Pengaruh yang diberikan kompetensi profesional guru terhadap prestasi belajar PPKn siswa merupakan pengaruh yang positif, jadi jika kompetensi profesional guru semakin baik maka akan semakin baik pula prestasi belajar PPKn siswa. Banyaknya kontribusi yang diberikan oleh guru untuk mencapai keberhasilan proses pendidikan, maka guru hendaknya selalu berusaha untuk mengembangkan kompetensinya dari segala aspek agar dapat menunjang kinerjanya dalam menjalankan profesi sebagai pendidik. Guru yang profesional bukanlah suatu fakta yang dapat terwujud dengan sendirinya, melainkan usaha yang terus menerus dilakukan agar profesionalitas seorang guru dapat terwujud. 
Hipotesis ketiga yang terdapat dalam penelitian ini adalah terdapat hubungan yang positif dan signifikan pada kompetensi pedagogis dan kompetensi profesional guru PPKn dengan prestasi belajar siswa di SMA Negeri se-Kota Yogyakarta. Berdasarkan hasil analisis yang telah dilakukan untuk melihat korelasi variabel kompetensi pedagogis dan kompetensi profesional guru PPKn dengan prestasi belajar siswa SMA Negeri se-Kota Yogyakarta dapat diketahui bahwa nilai $\mathrm{f}_{\text {hitung }}$ lebih besar daripada $\mathrm{F}$ tabel $(0,898>0,605)$ dan memiliki nilai signifikansi kurang dari 0,05 yaitu 0,001 $(0,001<0,05)$, sehingga dapat disimpulkan bahwa $\mathrm{Ha}_{3}$ diterima yaitu terdapat hubungan yang positif dan signifikan pada kompetensi pedagogis dan kompetensi profesional guru PPKn dengan prestasi belajar siswa SMA Negeri se-Kota Yogyakarta. Untuk mengetahui kontribusi dari masing-masing variabel $\mathrm{X}\left(\mathrm{X}_{1}\right.$ dan $\left.\mathrm{X}_{2}\right)$ dengan variabel $\mathrm{Y}$ dapat dilihat Nilai $\mathrm{R}$ square yang kemudian dikalikan $100 \%$.

Berdasarkan hasil analisis yang telah dilakukan untuk melihat korelasi variabel kompetensi pedagogis dan kompetensi profesional guru PPKn dengan prestasi belajar siswa SMA Negeri se-Kota Yogyakarta dapat diketahui bahwa nilai $\mathrm{f}$ hitung lebih besar daripada $\mathrm{F}_{\text {tabel }}(0,898>0,605)$ dan memiliki nilai signifikansi kurang dari 0,05 yaitu 0,001 $(0,001<0,05)$, sehingga dapat disimpulkan bahwa $\mathrm{Ha}_{3}$ diterima yaitu terdapat hubungan yang positif dan signifikan pada kompetensi pedagogis dan kompetensi profesional guru PPKn dengan prestasi belajar siswa SMA Negeri se-Kota Yogyakarta. Hasil analisis regresi Linier berganda dapat dilihat bahwa nilai R Square adalah 0,807 kemudian nilai $\mathrm{R}$ Square tersebut dikalikan $100 \%$, yang menghasilkan $80,7 \%$. Jadi dapat disimpulkan bahwa kontribusi variabel kompetensi pedagogis guru dan kompetensi profesional guru PPKn secara bersama-sama terhadap prestasi belajar PPKn siswa SMA Negeri seKota Yogyakarta adalah 80,7 \%. Dengan demikian sisa dari selain kontribusi kompetensi pedagogis guru dan kompetensi profesional adalah 19,3\% maka ada faktor lain yang dapat mempengaruhi prestasi belajar PPKn siswa di SMA Negeri se-Kota Yogyakarta.

Skourdoumbis (2014, hal. 111-112) menjelaskan bahwa, untuk menciptakan proses pembelajaran yang berkualitas, maka faktor guru perlu di perhatikan, karena apa yang guru lakukan, secara khusus pedagogis guru memiliki dampak lebih besar terhadap keberhasilan siswa dibandingkan dengan faktor-faktor lainnya. Adapun pedagogi guru pada proses pembelajaran adalah semua aspek tentang praktikum guru, misalnya, perencanaan pembelajaran yang dibuat, penilaian terhadap perkembangan siswa, pengembangan kurikulum yang dilakukan guru dan lain sebagainya. Penelitian yang dilakukan oleh Skourdoumbis (2014, hal. 122) menyimpulkan efektivitas guru pada proses pembelajaran adalah solusi untuk meningkatkan prestasi belajar siswa. Di sisi lain, untuk reformasi pendidikan modern memerlukan guru profesional yang tidak hanya memiliki pengetahuan tetapi juga harus memiliki keahlian yang baik, dapat mengatur kapasitas untuk kegiatan mengajar, dan mampu membimbing siswa dan memiliki kapasitas untuk mengeksplorasi pengajaran (Jiang, 2017). Maksudnya bahwa guru tidak hanya menjadi instruktur, tetapi juga penyelenggara, pemandu peserta, membantu siswa untuk belajar dan mampu menciptakan suasana belajar yang nyaman dan menyenangkan. Banyaknya kontribusi yang diberikan oleh guru untuk mencapai keberhasilan proses pendidikan, maka guru hendaknya selalu berusaha untuk mengembangkan kompetensinya dari segala aspek agar dapat menunjang kinerjanya dalam menjalankan profesi sebagai pendidik.

\section{Simpulan}

Semakin baik kompetensi pedagogis dan kompetensi profesional guru, semakin baik pula prestasi belajar PPKn siswa SMA Negeri se-Kota Yogyakarta. Demikian pula sebaliknya, semakin rendah kompetensi pedagogis dan profesional guru, semakin rendah pula prestasi belajar PPKn siswa SMA Negeri se-Kota Yogyakarta. Guru Pendidikan 
kewarganegaraan

mempertahankan kompetensi guru yang sudah dimilikinya, salah satunya dengan cara memberdayakan Forum Musyawarah Guru Mata Pelajaran (MGMP).

\section{Referensi}

Akiba, M., \& Liang, G. (2016). Effects of teacher professional learning activities on student achievement growth. The Journal of Educational Research, 109(1), 99-110. https://doi.org/10.1080/00220671.2014.9 24470

An, X., Hannum, E. C., \& Sargent, T. (2008). Teaching quality and student outcomes: academic achievement and educational engagement in rural Northwest China. Education, 5(2), 309-334.

Connell, R. (2009). Good teachers on dangerous ground: Towards a new view of teacher quality and professionalism. Critical studies in education, 50(3), 213-229.

Hamalik, O. (2009). Pendidikan guru berdasarkan pendekatan kompetensi. Jakarta: Bumi Aksara.

Indra, S. (2016). Pengaruh kompetensi pedagogik dan kompetensi profesional guru pai terhadap prestasi belajar pai pada siswa di SMK Farmako Medika Plus Cringin Bogor. Institut Agama Islam Negeri Surakarta.

Jiang, Y. (2017). A study on professional development of teachers of english as a foreign language in institutions of higher education in Western China. Verlag $\mathrm{GmbH} \quad$ Germany: Springer. https://doi.org/10.1007/978-3-66253637-7_7

Kosunen, T., \& Mikkola, A. (2002). Building a Science of Teaching: How objectives and reality meet in Finnish teacher education. European Journal of Teacher Education, 25(2-3), $135-150$. https://doi.org/10.1080/02619760220000 35674

Lee, H.-J., \& Rha, I. (2009). Influence of structure and interaction on student achievement and satisfaction in web-based distance learning. Journal of Educational Technology \& Society, 12(4), 372.
Loughran, J., Berry, A., \& Mulhall, P. (2012). Pedagogical content knowledge. Understanding and developing science teachers' pedagogical content knowledge. https://doi.org/10.1007/978-94-6091821-6

Payong, M. R. (2011). Sertifikasi profesi guru. Konsep dasar,problematika, dan implementasinya. Jakarta: Indeks Permata Puri Media.

Skourdoumbis, A. (2014). Teacher effectiveness: making the difference to student achievement? British journal of educational studies, 62(2), 111-126.

Sugiyono. (2012). Metode penelitian kuantitatif kualitatif dan $R \& D$. Bandung: Alfabeta.

Tatar, E., Tüysüz, C., Tosun, C., \& İlhan, N. (2016). Investigation of factors affectings students' science achievement according to student science teachers. International Journal of Instruction, 9(2), 153-166. https://doi.org/10.12973/iji.2016.9211a

Widarsih, R., \& Faraz, N. J. (2016). Evaluasi kinerja guru IPS SMP berdasarkan standar kompetensi guru di Kabupaten Kebumen. Harmoni Sosial: Jurnal Pendidikan IPS, 3(2), 177. https://doi.org/10.21831/hsjpi.v3i2.7646

Wulandari, D. (2012). Pengaruh kompetensi pedagogik dan kompetensi profesional guru terhadap economic literacy melalui prestasi belajar siswa kelas XII IPS di SMA Kota Malang. Jurnal Pendidikan Humaniora, 1(1), 25-29. 